\title{
ISOLATION AND IDENTIFICATION OF $\alpha$-GLUCOSIDASE INHIBITORY COMPOUNDS FROM ETHYL ACETATEEXTRACT OF Sirih Hijau (Piper betle L.)
}

\author{
A. Malik ${ }^{1,2}$, L. Marpaung ${ }^{1 *}$, M. P. Nasution ${ }^{1}$ and P. Simanjuntak ${ }^{3,4}$ \\ ${ }^{1}$ Departmentof Chemistry, Universitas Sumatera Utara, 20155, (Sumatera Utara) Indonesia \\ ${ }^{2}$ Department of Physics, Universitas Almuslim, 24261, (Aceh) Indonesia \\ ${ }^{3}$ Biotechnology Research Center, Indonesian Institute of Sciences, 16911, (Jawa Barat) \\ Indonesia \\ ${ }^{4}$ Faculty of Pharmacy, Pancasila University, 12640, (Jakarta) Indonesia \\ * E-mail: lamekhmarpaung@gmail.com
}

\begin{abstract}
It has been ascertained that the extract of sirih hijau (Piper betle Linn) possesses some bioactivities, particularly its ability to inhibit the $\alpha$-glucosidase enzyme. However, certain compounds contained in the betel leaf extract which can act as glucosidase enzyme inhibitors are not widely known. In this research, betel leaves were air-dried and mashed into dry powder. The dry powder was macerated in methanol and filtered, and the isolate results were partitioned successively with $n$-hexane and ethyl acetate. The isolation of the compound was done by column chromatography using silica gel 60 mesh as the stationary phase and a mixture of chloroform-methanol (9:1, v/v; and $8: 2, \mathrm{v} / \mathrm{v}$ ). Four fractions were obtained with various combinations of solvents, one of which was a mixture of benzene-ethyl acetate $(7: 3, \mathrm{v} / \mathrm{v})$ which resulted in a pure isolate. The structure of the isolated molecule was determined by using the spectroscopy procedure based on ultraviolet-visible, infra-red, and nuclear magnetic resonances spectroscopy. It gave rise to $\alpha$-glucosidase inhibitory potential evaluated in vitro based on UV-Vis spectrometry. An isolated compound, identified as 2-hydroxychavicol, was successfully isolated from Piper betel leaves. The compound has an $\alpha$-glucosidase inhibitory potential with $\mathrm{IC}_{50}$ value of $72,87 \mathrm{ppm}$.
\end{abstract}

Keywords: $\alpha$-Glucosidase, Antidiabetic, Ethyl Acetate, NMR Spectra, Piper betle Linn, Sirih hijau

(C) RASĀYAN. All rights reserved

\section{INTRODUCTION}

The betel or sirih hijau (Piper betle L.) is one of the most important medicinal plants closely associated with the (Southeast) Asian culture. In this region, it is the second most daily consumed plant after coffee and tea. In recent years, several studies related to the influence of betel extract and chemical contents of betel plants on biological activities (both in vitro and in vivo) have been published. Their results showed that extracts, fractions, and pure compounds from betel leaves play an important role in oral hygiene, antidiabetic, antiulcer, cardiovascular, antiinfective, and hepatoprotective $\mathrm{e}^{1,2}$.

Phytochemical analysis of an ethanolic extract from Piper betle leaves showed the presence of tannins, anthraquinones, flavonoids, terpenoids, glycosides, and reducing sugars ${ }^{3}$. Betel leaf essential oil is a good antifungal agent against Aspergillus flavus ${ }^{4}$. After being tested on sago starch film, betel leaf extracts showed antimicrobial activity against several gram-positive and gram-negative bacteria except for the Pseudomonas aeruginosa bacteria which do not show any influence of betel leaf extract on any levels ${ }^{5,6}$.

There are at least two reports about the utilization of betel leaf extract as a herbal remedy for antidiabetic. The first one concluded that hot water extract (HWE) and cold ethanol extract (CEE) significantly lower the blood sugar level of normoglycaemic rats. Furthermore, it revealed that no toxins are found within both extracts, and they are well-accepted (i.e. no signs of poisoning, liver disorders, or renotoxicity) by the body after being given orally.

Rasayan J. Chem., 12(3), 1175-1184(2019)

http://dx.doi.org/10.31788/RJC.2019.1235082

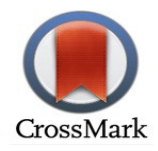


Thus, it can be concluded that HWE and CEE of betel leaves are safe to be used, and they possess a strong antidiabetic activity ${ }^{7}$.In the other report, an in vitro analysis of betel leaf ethanol extract showed inhibitory effects on $\alpha$-amylase enzyme. This inhibitory activity against $\alpha$-amylase enzyme has a positive correlation with the total phenolic content of the betel leaf ethanol extract ${ }^{8}$.

It is generally accepted that several plants showing the potential hypoglycaemic contain high phenolic compounds such as Phyllantusniruri L, Smilax officinalis, Ilex paraguayensis A.St.-Hil., and Tagetesminuta, and they have strong inhibitory effects against $\alpha$-glucosidase activity ${ }^{9}$. The $\alpha$-glucosidase is known as an important enzyme for sugar metabolism in the body. Some of the new bioactive compounds such as epigallocatechingallate, beta-pyrazol-1-yl-1-alanine, leucocyandin3-O-beta-Dgalactosyl cellobiosides, leucopelargonidin-3-O-alpha-Lrhamnosides, glycyrrhetinic acid, dehydrotrametenoic acid, strictinin, isotrictinin, pedunculagin, epicatechin, and christinin-A have been successfully isolated from these plants, i.e. Allium sativum, Gymnemasylvestre, Citrulluscolocynthis, Trigonellafoenum-graecum, Momordicacharantia, and Ficusbengalensis, all of which exhibit a strong antidiabetic activity which exceeds conventional antidiabetic agents ${ }^{10}$. This article discusses isolation and identification of the compound structure of the betel leaf ethyl acetate extract and an in vitro analysis of $\alpha$-glucosidase inhibitors of the compounds.

\section{Materials and Methods}

\section{EXPERIMENTAL}

The fresh betel leaves used for the research were purchased at a local wet market in Aceh, Indonesia, and they belong to the species of Piper betle L., a perennial plant that creeps and grows into a large bush with thick heart-shaped leaves. The leaves are commonly used for the purpose of chewing and traditional medicine. The identity of Piper betle L. had been determined by taxonomists at the Biology Research Center(Herbarium Bogoriense; Voucher Number:1891/IPH.1.01/If.07/VII/2017), Indonesian Institute of Sciences, Indonesia.

Sodium carbonate, dimethylsulfoxide, a-glucosidase enzyme, phosphate buffer, p-nitrophenil-a-Dglucosidase were supplied by Sigma-Aldrich ${ }^{\circledR}$ (St. Louis, MO, USA). Methanol, ethanol, ethyl acetate, and acetone were purchased from Rudang Chemicals (Medan, Indonesia). All the chemicals and reagents used in this study were analytical-grade.

The instruments used in this research include chemical glasses, reflux apparatus, rotary evaporator, water bath, erlenmeyer flask, separating funnel, column chromatography, the TLC, UV lamp, UV-Vis spectrophotometer, IR spectrophotometer, and NMR spectrometers. The chemicals used in the study include methanol, $n$-hexane, ethyl acetate, chloroform, benzene, acetone, $\mathrm{HCL}, \mathrm{FeCl}_{3}$, aquadest, and silica powder.

\section{General Procedure}

Extraction was done according to a procedure reported previously ${ }^{11}$ with slight modification. First, betel leaf (6000 g) was air-dried for 7x24 hours before they were ground into betel leaf dried powder (1233 g) using a leaf polishing machine. Then, the dried powder was macerated in methanol (12 L) for $2 \times 24$ hours. Afterward, the dried powder was filtered, and the filtrate was evaporated by using the rotary evaporator.

The concentrated methanol extract of the betel leaves was diluted with aquadest, filtered, and partitioned gradually with n-hexane followed by ethyl acetate (1:1) until the fraction of ethyl acetate was tested negative in the phenolic test. Next, the fraction of the ethyl acetate was evaporated to obtain the total phenolic $(4.56 \mathrm{~g})$. Then the total phenolic content was pre-loaded to be absorbed into silica gel and subjected to Colom Chromatography by using a mixture of $\mathrm{CHCl}_{3}-\mathrm{MeOH}$ with increasing polarity (10:0 $\rightarrow$ 0:10) to give four fractions (A16 - A19). Preparative TLC was applied to purifyfractions ${ }^{12}$ A17 (3380 $\mathrm{mg}$ ) and $\mathrm{A} 16(250 \mathrm{mg})$ using $\mathrm{C}_{6} \mathrm{H}_{6}-\mathrm{EtOAc}(7: 3)$ to obtain isolate $(10 \mathrm{mg})$.

\section{Detection Method}

The structure of the isolate was determined based on its UV-Vis, IR, and NMR spectrum. UV-Vis spectrum was measured at a wavelength from $200-500 \mathrm{~nm}$ by using UV-Vis spectrometer variant 100 conc. IR spectrum was measured on the frequency $500-4500 \mathrm{~cm}^{-1}$ by using FTIR Prestige 21 
Spectrometer (Shimadzu, Japan), whereas the spectrum of NMR was measured at $2.9-6.9 \mathrm{ppm}$ to ${ }^{1} \mathrm{H}$ NMR and $12-154 \mathrm{ppm}$ for ${ }^{13} \mathrm{C}$ NMR by using Agilent DD2 (console system) NMR spectrometer that operates at $500 \mathrm{MHz}\left({ }^{1} \mathrm{H} \mathrm{NMR}\right)$ and $125 \mathrm{MHz}\left({ }^{13} \mathrm{C}\right.$ NMR).

The NMR spectrum is equipped with information of its heteronuclear single quantum correlation (HSQC) to evaluate hydrogen-carbon relationship in a single bond, distortionless enhancement polarization transfer (DEPT) sequence to evaluate the kinds of carbon atoms (primary, secondary, tertiary, or quaternary), heteronuclear multiple bond correlation (HMBC) to evaluate carbon interaction with the hydrogen of neighboring carbons up to two ties, and correlation spectroscopy (COSY) to evaluate the hydrogen interaction with the hydrogen of its nearest carbon.

The assay of antidiabetic activities of pure compounds isolated from the ethyl acetate extract of betel leaves was observed based on its ability to inhibit activities of the $\alpha$-glucosidase enzyme. $\alpha$-Glucosidase inhibition was evaluated according to a method reported previously with slight modification ${ }^{9}$. The results of the reaction absorbance were collected at $\lambda 400 \mathrm{~nm}$ by using UV-Vis spectrophotometer. The inhibitory percentage was calculated by the equation (1), as-

$$
\% \text { Inhibition }=\frac{(c-s)}{c} \times 100 \%
$$

Where,

$C=$ absorbance (control - blank)

$S=$ absorbance $\mathrm{si}-\mathrm{s} 0$

The value of $\mathrm{IC}_{50}$ (inhibition concentration $50 \%$ ) is the concentration when percent inhibition reaches $50 \%$.

\section{RESULTS AND DISCUSSION}

The dark brown isolate liquid showed the maximum UV absorbance at 218 and $283 \mathrm{~nm}$. There was a UV absorbance shift at $\mathrm{pH} 13$ which was diagnosed as the result of $-\mathrm{OH}$ existence. It was indicated that the isolate was a phenolic compound. The intensity of the $K$-band was at $283 \mathrm{~nm}$ which is a characteristic of a chromophore that is conjugated with an aromatic ring ${ }^{13}$.

IR absorption band which was at 3076,46; 1521,84; and 3373,50 $\mathrm{cm}^{-1}$ indicated the presence of aromatic $\mathrm{C}-\mathrm{H}, \mathrm{C}=\mathrm{C}$, and hydroxyl groups, which are in accordance with the presence of a phenol skeleton. The presence of an absorption band at $2922,16 \mathrm{~cm}^{-1}$ was in accordance with an aliphatic carbon chain (C-C). One sharp absorption peak at $648,08 \mathrm{~cm}^{-1}$ indicated the presence of double bonds $(\mathrm{C}=\mathrm{C})$ on the aliphatic chain, while the sharp absorption peak at $1282,66 \mathrm{~cm}^{-1}$ indicated the presence of $\mathrm{C}-\mathrm{O}-$.

The ${ }^{1} \mathrm{H}$ NMR spectrum of the isolate showed the presence of three signals at $\delta_{\mathrm{H}} 6,47-6,66 \mathrm{ppm}$ range, which was an area of aromatic proton peaks. The signal at the $\delta_{\mathrm{H}} 6,66 \mathrm{ppm}(1 \mathrm{H}, \mathrm{d}, J=8,0 \mathrm{~Hz}, \mathrm{H}-6)$ represents an aromatic proton which has another proton. The signal at $\delta_{\mathrm{H}} 6.60 \mathrm{ppm}(1 \mathrm{H}, \mathrm{s}, \mathrm{H}-3)$ represents a proton which does not have an ortho proton, whereas the signal at $\delta_{\mathrm{H}} 6,47 \mathrm{ppm}(1 \mathrm{H}, \mathrm{d}, J=8,0 \mathrm{~Hz}, \mathrm{H}-5)$ was a proton peak that has an ortho proton. Because there were no other aromatic protons at this stage, it was certain that both proton H-5 and H-6 must be neighbors (Fig.-1).

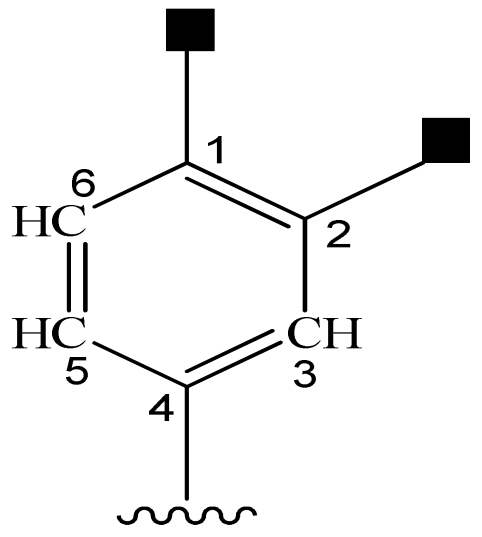

Fig.-1: Aromatic Rings of Isolate. 


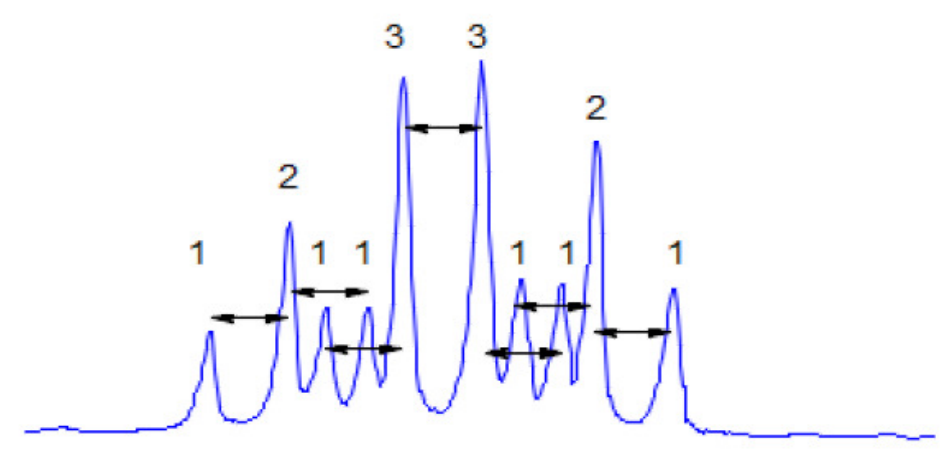

Fig.-2: The ${ }^{1} \mathrm{H}$ NMR Spectrum of H-8.

There were five aliphatic proton peaks. The signal at the $\delta_{\mathrm{H}} 5,91 \mathrm{ppm}(1 \mathrm{H}, \mathrm{m}, \mathrm{H}-8)$ was an aliphatic proton peak with four vicinal protons. The total intensity of all the peaks, $2^{\mathrm{n}}$, is 16 in which $\mathrm{n}$ is the number of its vicinal protons, and founded $n=4$ based on ${ }^{1} \mathrm{H}$ NMR H-8 spectrum (Fig.-2). In other words, proton $\mathrm{H}-8$ has 4 vicinal protons. ${ }^{14}$

The signal at the $\delta_{\mathrm{H}} 4.99 \mathrm{ppm}\left(2 \mathrm{H}, \mathrm{dd}, J_{8.9 \mathrm{a}}=19,10 \mathrm{~Hz} ; J_{8.9 \mathrm{~b}}=10,15 \mathrm{~Hz}, \mathrm{H}-9\right)$ is a peak of two protons, which have a vicinal proton. The value of the scalar coupling of the peak, $J$, indicated that the two protons were tied to a carbon atom which was double bonded with other carbons. Such a proton cannot spin freely on its axis. Thus, the protons have a different position against his vicinal proton ${ }^{15}$. The difference in position generates two doublet peaks which were overlapped between trans $\left(J_{8.9 \mathrm{a}}=19,10 \mathrm{~Hz}\right)$ and cis $\left(J_{9 \mathrm{a} .9 \mathrm{~b}}=10,15 \mathrm{~Hz}\right)$ conformation.

The signal at the $\delta_{\mathrm{H}} 3,21 \mathrm{ppm}(2 \mathrm{H}, \mathrm{d}, J=6,7 \mathrm{~Hz}, \mathrm{H}-7)$ corresponded to the two protons which have one vicinal proton. These protons were obviously tied to a carbon atom that has a single bond with the other carbon atom, so it can spin freely around the axis. As a result, the two protons have a relatively identical position to that of the vicinal proton, and they appear as a doublet peak. The structure of the remaining five protons was shown in Fig.-3.

The ${ }^{13} \mathrm{C}$ NMR spectrum of the isolate showed nine main peaks, indicating that the isolate has nine carbon atoms. Some peaks appeared on the hetero-aromatic and the aromatic carbon atom areas at around $\delta_{\mathrm{C}} 100-$ $160 \mathrm{ppm}$. With nine carbons, the isolate has just one aromatic ring formed by six carbon atoms, and the other three carbon atoms were most likely aliphatic carbon atoms. It was assumed that the isolate only consists of two parts (Fig.-1 and Fig.-2). The peak at $\delta_{\mathrm{C}} 40,59$ ppm represents a secondary carbon of aliphatic chain, C-7. It concurred with the carbon chain prediction as recommended earlier (Fig.-2).

The two peaks which appear in the aromatic carbon area toward lower field at $\delta_{\mathrm{C}} 146,14 \mathrm{ppm}$ and $\delta_{\mathrm{C}}$ $144,44 \mathrm{ppm}$ indicate both carbon atoms were most likely bound to an atom which has a high electronegative oxygen atom from the hydroxyl group. This fact was supported by the data from the IR spectrum which showed the presence of a wide peak at $3373,50 \mathrm{~cm}^{-1}$ as $-\mathrm{OH}$ group.

The COSY NMR spectrum of the isolate (Fig.-4) showed that the proton signals at $\delta_{\mathrm{H}} 5,91 \mathrm{ppm}(\mathrm{H}-8)$ cross-peak with the proton signals at $\delta_{\mathrm{H}} 3,21 \mathrm{ppm}(\mathrm{H}-7)$ and proton signals at $\delta_{\mathrm{H}} 4,99 \mathrm{ppm}(\mathrm{H}-9)$. It was indicated that both H-7 and H-9 were vicinal protons of H-8 (Fig.-2). However, the proton signals at $\delta_{\mathrm{H}}$ $6,66 \mathrm{ppm}(\mathrm{H}-6)$ cross-peak with the proton signals at $\delta_{\mathrm{H}} 6,47 \mathrm{ppm}(\mathrm{H}-5)$ which revealed that $\mathrm{H}-5$ was an ortho proton of the H-6 (Fig.-1).

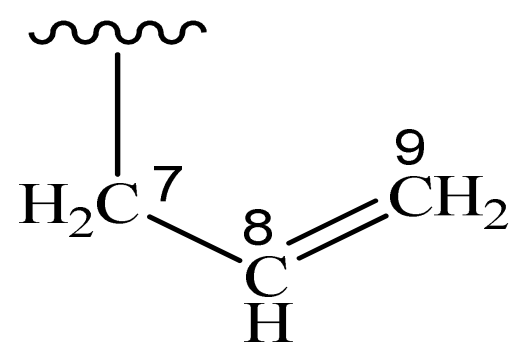

Fig.-3: Aliphatic Carbon Chains of Isolate. 
RASĀYAN J. Chem.

Vol. 12 | No. 3 |1175 - 1184| July - September | 2019

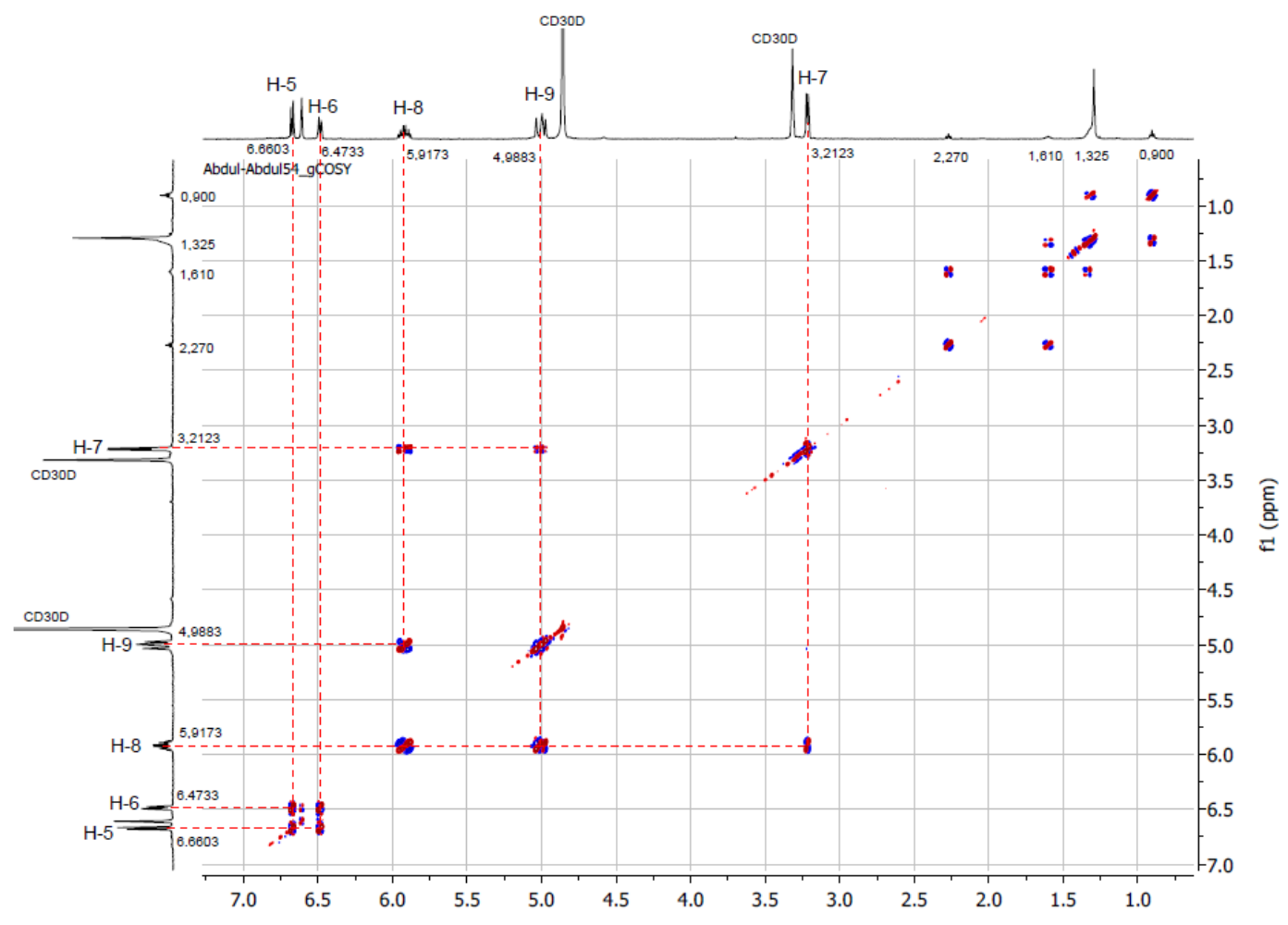

Fig.-4: COSY NMR Spectrum of Isolate.

The relationship between hydrogen and carbon which bonded them together was analyzed based on the HSQC NMR spectrum of the isolate (Fig.-5). The spectrum showed that carbon signals at $\delta_{\mathrm{C}} 146,14 \mathrm{ppm}$ $(\mathrm{C}-2), \delta_{\mathrm{C}} 144,44 \mathrm{ppm}(\mathrm{C}-1)$, and $\delta_{\mathrm{C}} 132,91 \mathrm{ppm}(\mathrm{C}-4)$ have not interacted with any protons. This means those three aromatic carbon atoms were not protonated (Fig.-1). The cross peak that took place between carbon atom signals at $\delta_{\mathrm{C}} 139,53 \mathrm{ppm}(\mathrm{C}-8)$ and proton signals at $\delta_{\mathrm{H}} 5,91 \mathrm{ppm}$ showed that C-8 was protonated by one proton $(\mathrm{H}-8)$. Although the peak was equally visible in the aromatic areas, $\mathrm{C}-8$ was definitely non-aromatic because it was protonated by non-aromatic protons. The signals at $\delta_{\mathrm{C}} 120,78 \mathrm{ppm}$ $(\mathrm{C}-5), \delta_{\mathrm{C}} 116,70 \mathrm{ppm}(\mathrm{C}-3), \delta_{\mathrm{C}} 116,25 \mathrm{ppm}(\mathrm{C}-6)$ were obviously the three aromatic carbon peaks. Furthermore, they appear in the aromatic areas, and they cross peak with aromatic proton signals at $\delta_{\mathrm{H}}$ $6,47 \mathrm{ppm}(\mathrm{H}-5) ; \delta_{\mathrm{H}} 6,61 \mathrm{ppm}(\mathrm{H}-3)$; and at $\delta_{\mathrm{H}} 6,66 \mathrm{ppm}(\mathrm{H}-6)$. The carbon signals at $\delta_{\mathrm{C}} 115,24 \mathrm{ppm}(\mathrm{C}-9)$ cross-peak with the proton signals at $\delta_{\mathrm{H}} 4.99 \mathrm{ppm}(2 \mathrm{H}, \mathrm{H}-9)$.

The DEPT spectrum informed that C-9 was protonated by two protons. Although the peaks appear in the aromatic peak areas, they are not an aromatic carbon because they were protonated with a non-aromatic proton H-9. Based on the proton peak, as described earlier, C-9 must have double bonds, $=\mathrm{CH}_{2}$. The signals at $\delta_{\mathrm{C}} 40,59 \mathrm{ppm}(\mathrm{C}-7)$ cross-peak with the proton signals at $\delta_{\mathrm{H}} 3.21 \mathrm{ppm}(2 \mathrm{H}, \mathrm{H}-7)$. This means that C-7 was protonated by two protons $\mathrm{H}-7$. This was reinforced by the DEPT spectrum, which suggests that $\mathrm{C}-7$ was a methylene, $-\mathrm{CH}_{2}{ }^{16}$. Based on the explanations of the ${ }^{1} \mathrm{H}$ NMR spectrum earlier, $\mathrm{C}-7$ does not have double bonds. In other words, $\mathrm{C}-7$ was not a part of the aromatic carbons.

The connectivity between protons and carbons within 2 to 3 bonds was analyzed based on the HMBC NMR spectrum (Fig.-6). The cross peaks between proton peaks $\left\{\right.$ at $\delta_{\mathrm{H}} 6,61 \mathrm{ppm}(1 \mathrm{H}, \mathrm{H}-3), \delta_{\mathrm{H}} 6,47 \mathrm{ppm}$ $(1 \mathrm{H}, \mathrm{H}-5), \delta_{\mathrm{H}} 5,92 \mathrm{ppm}(1 \mathrm{H}, \mathrm{H}-8)$, and $\left.\delta_{\mathrm{H}} 4,99 \mathrm{ppm}(2 \mathrm{H}, \mathrm{H}-9)\right\}$ and the carbon peak at $\delta_{\mathrm{C}} 39.20 \mathrm{ppm}(\mathrm{C}-$ 7) showed a hetero multiple-bond relationship between the protons $\{\mathrm{H}-3, \mathrm{H}-5, \mathrm{H}-8$, and H-9 $\}$ and carbon C-7. The hetero multiple-bond relationship between the proton $\mathrm{H}-7$ and carbons $\{\mathrm{C}-8, \mathrm{C}-4, \mathrm{C}-5, \mathrm{C}-3$, and $\mathrm{C}-9\}$ is shown by the intersection of signal protons at $\delta_{\mathrm{H}} 3.21 \mathrm{ppm}(2 \mathrm{H}, \mathrm{H}-7)$ with carbon signals at $\delta_{\mathrm{C}}$ $139,53 \mathrm{ppm}(\mathrm{C}-8) ; \delta_{\mathrm{C}} 132,91 \mathrm{ppm}(\mathrm{C}-4) ; \delta_{\mathrm{C}} 120,78 \mathrm{ppm}(\mathrm{C}-5) ; \delta_{\mathrm{C}} 116,70 \mathrm{ppm}(\mathrm{C}-3)$; and $\delta_{\mathrm{C}} 115,24 \mathrm{ppm}$ (C-9). This also shows that the aromatic rings are connected with aliphatic carbon chains through carbon C-4 (Fig.-7 (a)). Therefore, the two hydroxyl groups must be bound with carbons at $\delta_{\mathrm{C}} 144,44 \mathrm{ppm}$ and $\delta_{\mathrm{C}}$ 146,14 ppm respectively. 
RASĀYAN J. Chem.

Vol. 12 | No. 3 |1175 - 1184| July - September | 2019

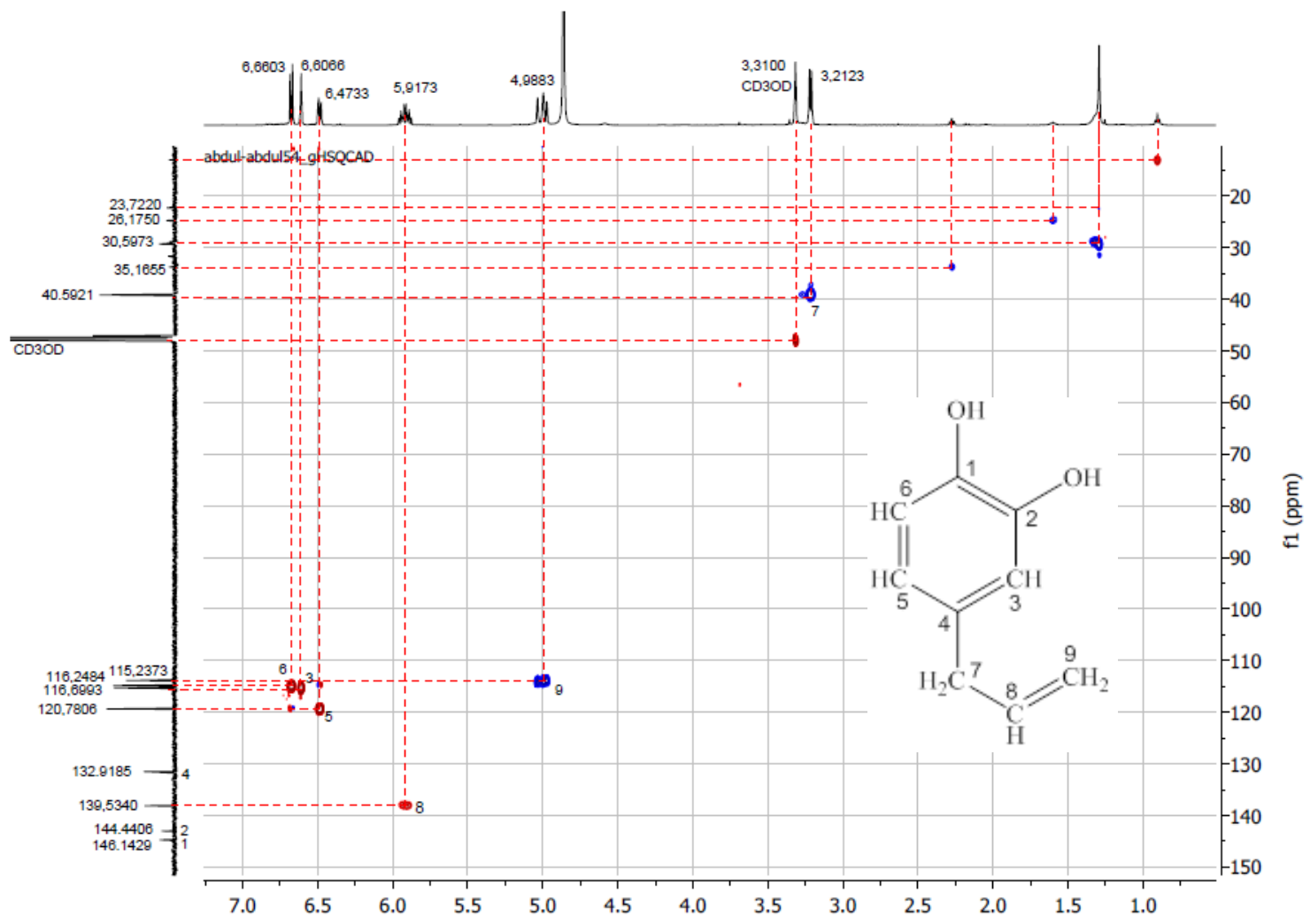

Fig.-5: HSQC NMR spectrum of Isolate.

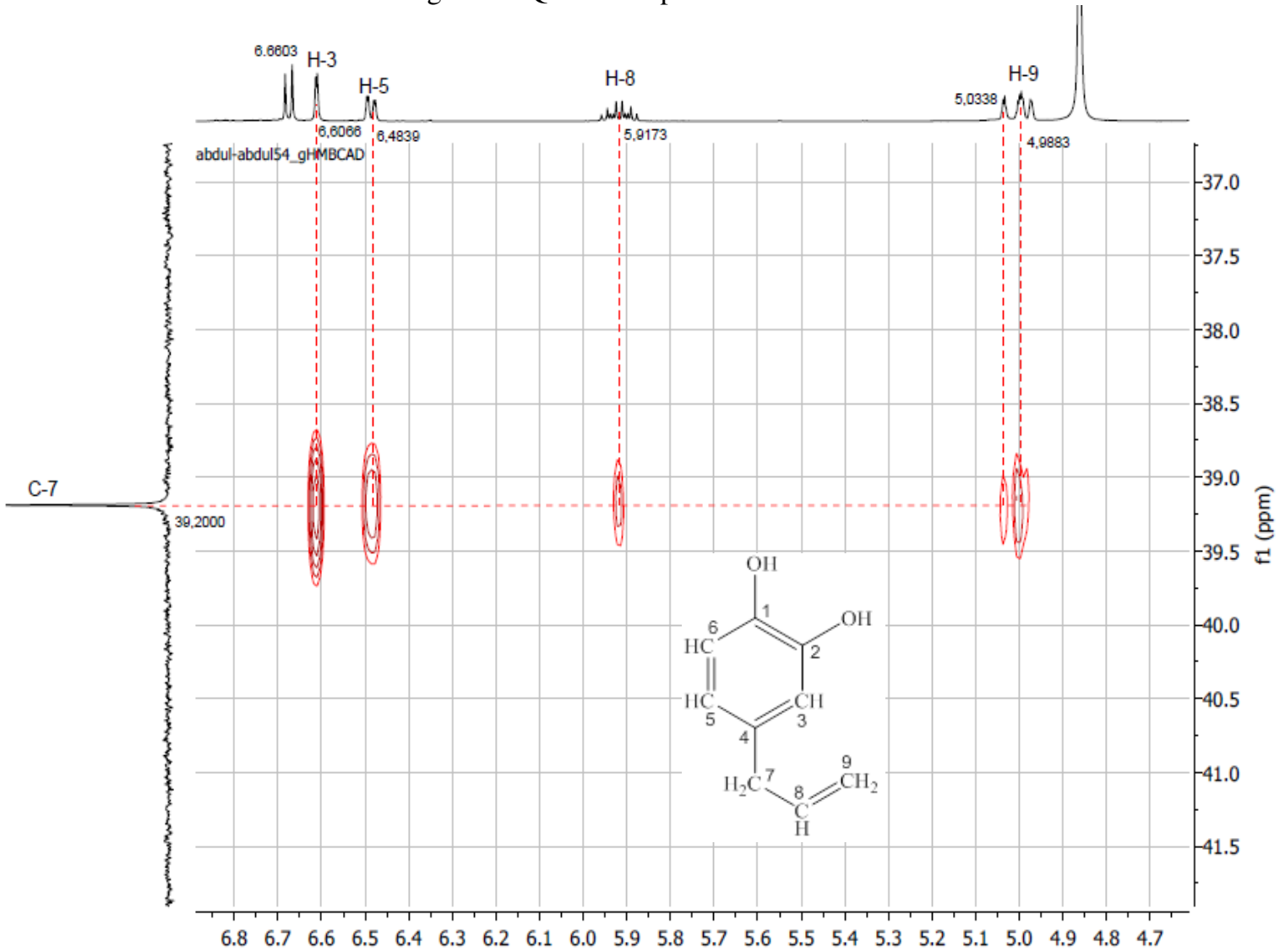

(a) 
RASĀYAN J. Chem.

Vol. 12 | No. 3 |1175 - 1184| July - September | 2019

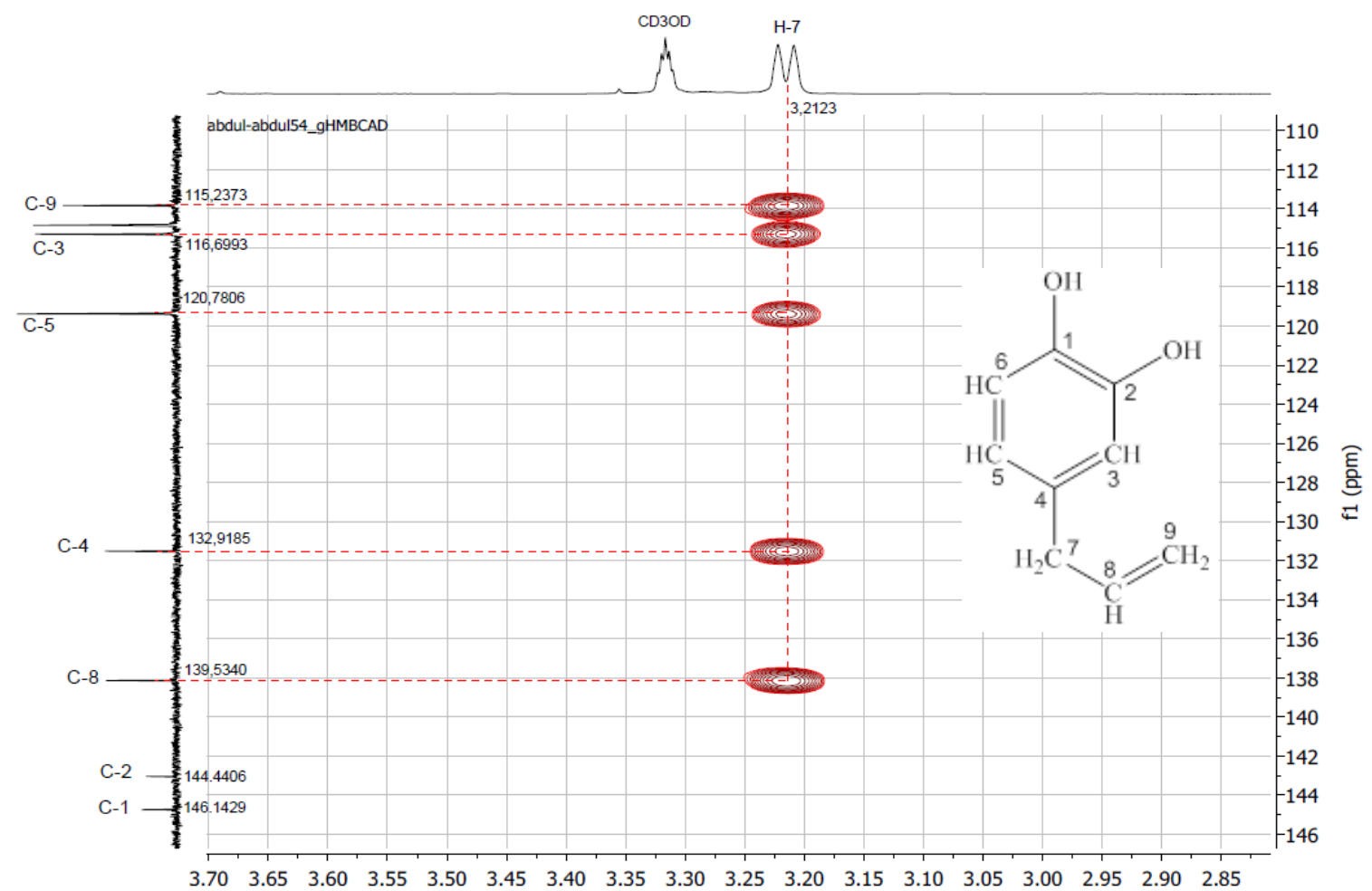

(b)

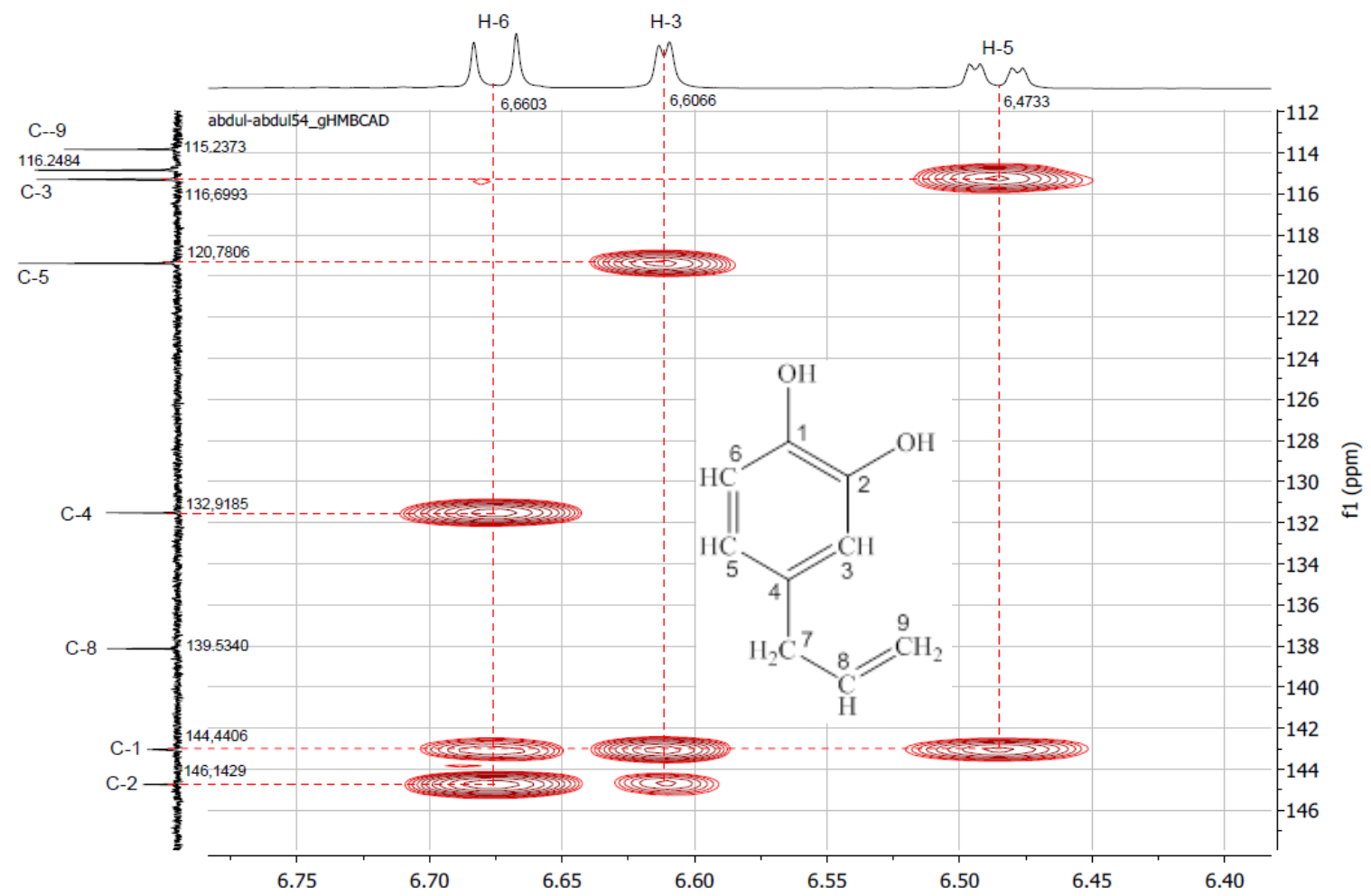

(c)

Fig.-6: HMBC NMR Spectrum of Isolate. (a) $\delta_{\mathrm{C}} 37,0-42,0 \mathrm{ppm}$; (b) $\delta_{\mathrm{C}} 110-146 \mathrm{ppm}$; (c) $\delta_{\mathrm{C}} 112-147 \mathrm{ppm}$.

The cross peak between carbon signal at $\delta_{\mathrm{C}} 146,14 \mathrm{ppm}(\mathrm{C}-2)$ and two proton signals $\left\{\right.$ at $\delta_{\mathrm{H}} 6,66 \mathrm{ppm}$ $(1 \mathrm{H}, \mathrm{H}-6)$ and at $\left.\delta_{\mathrm{H}} 6,61 \mathrm{ppm}(1 \mathrm{H}, \mathrm{H}-3)\right\}$ indicates that carbon C-2, as recommended (Fig.-7 (b)), has a 
RASĀYAN J. Chem.

Vol. 12 | No. 3 |1175 - 1184| July - September | 2019

hetero multiple-bond relationship with the protons H-3 and H-6. However, the intersection of the carbon peak at $\delta_{\mathrm{C}} 144,44 \mathrm{ppm}(\mathrm{C}-1)$ with three proton peaks $\left\{\delta_{\mathrm{H}} 6,66 \mathrm{ppm}(1 \mathrm{H}, \mathrm{H}-6) ; \delta_{\mathrm{H}} 6,61 \mathrm{ppm}(1 \mathrm{H}, \mathrm{H}-3)\right.$, and $\left.\delta_{\mathrm{H}} 6,47 \mathrm{ppm}(1 \mathrm{H}, \mathrm{H}-5)\right\}$ indicates that carbon $\mathrm{C}-1$ has multiple hetero relationships with the protons $\mathrm{H}-3$, $\mathrm{H}-5$, and $\mathrm{H}-6$.

The intersection between the carbon signal at $\delta_{\mathrm{C}} 132,91 \mathrm{ppm}(\mathrm{C}-4)$ and proton signals at $\delta_{\mathrm{H}} 6,66 \mathrm{ppm}(1 \mathrm{H}$, $\mathrm{H}-6)$ and $\delta_{\mathrm{H}} 3,21 \mathrm{ppm}(2 \mathrm{H}, \mathrm{H}-7)$ indicates a hetero multiple-bond relationship between the C-4 and protons $\mathrm{H}-6$ and $\mathrm{H}-7$. This strengthens the fact that C-4 was a point of connectivity between the aromatic rings and the aliphatic carbon chains in the isolate.

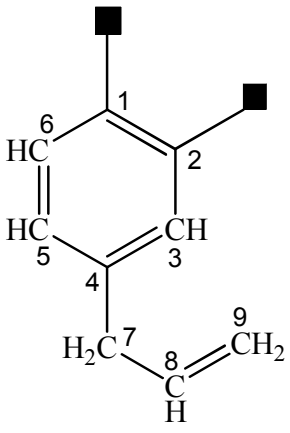

(a)

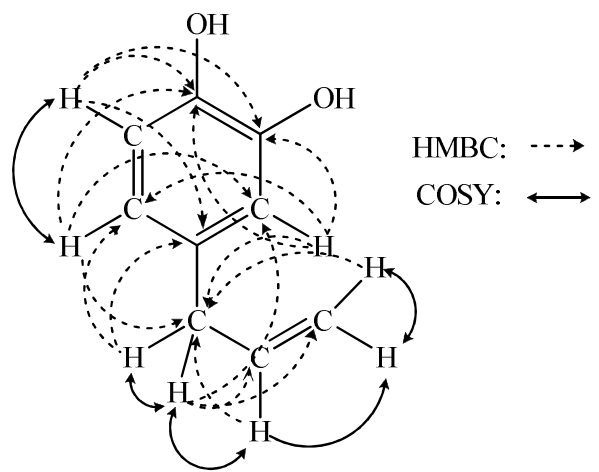

(b)

Fig.-7: HMBC NMR and COSY NMR relationship of Isolate.

In addition, the intersection between signal carbons at $\delta_{\mathrm{C}} 120,78 \mathrm{ppm}(\mathrm{C}-5)$ and proton signals at $\delta_{\mathrm{H}} 6,61$ ppm $(1 \mathrm{H}, \mathrm{H}-3)$ showed a long-range coupling relationship between carbon $\mathrm{C}-5$ and proton $\mathrm{H}-3$. Likewise, along with range coupling relationship between carbon $\mathrm{C}-3$ and proton $\mathrm{H}-5$ was indicated by the presence of an intersection between carbon signals at $\delta_{\mathrm{C}} 116,70 \mathrm{ppm}(\mathrm{C}-3)$ and proton signals at $\delta_{\mathrm{H}} 6,47 \mathrm{ppm}(1 \mathrm{H}$, H-5).

From the explanation above, some notes can be taken:

1. The Isolate consists of nine carbon atoms, six of which form an aromatic ring, and the other three carbon atoms form branches of aliphatic chains.

2. The aromatic ring is connected with the aliphatic carbon chains through carbons $\mathrm{C}-4$ and the ${ }^{13} \mathrm{C}$ NMR signals which appear at $\delta_{\mathrm{C}} 132,92 \mathrm{ppm}$.

3. The peaks at $\delta_{\mathrm{C}} 144,44 \mathrm{ppm}(\mathrm{C}-1)$ and $\delta_{\mathrm{C}} 146,14 \mathrm{ppm}(\mathrm{C}-2)$ are the carbon signals that are bounded with hydroxyl groups respectively.

4. The carbons at $\delta_{\mathrm{C}} 115,24 \mathrm{ppm}(\mathrm{C}-9)$ are bounded with the carbons at $\delta_{\mathrm{C}} 139,53 \mathrm{ppm}(\mathrm{C}-8)$ which are formed through double bonds.

Thus, according to the facts above, the most appropriate molecular structure of the isolate was the 2hydroxychavicol as suggested in (Fig.-8) in which the phenolic proton peaks were hidden under the olefinic multiplet ${ }^{19}$.<smiles>C=C[CH]c1ccc(O)c(O)c1</smiles>

Fig.-8: Chemical Structure of Isolate, 2-hydroxychavicol. 
RASĀYAN J. Chem.

Vol. 12 | No. 3 |1175 - 1184| July - September | 2019

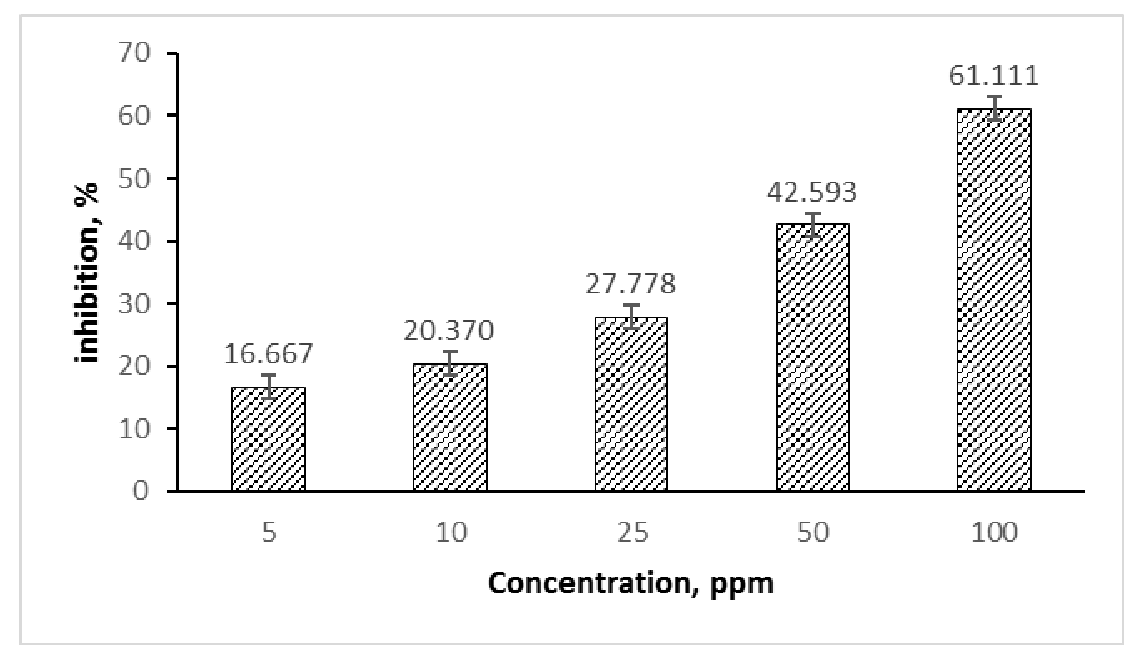

Fig.-9: Influences of 2-hydroxychavicol Concentration to $\alpha$-glucosidase Inhibitory.

\section{$\alpha$-Glucosidase Inhibitory Activity}

The antidiabetic test of the isolate, 2-hydroxychavicol, against $\alpha$-glucosidase enzyme was done by in vitro. The sample with a higher 2-hydroxychavicol concentration ranging at $5-100 \mathrm{ppm}$ exhibits a higher $\alpha$-glucosidase inhibitory activity. The increased dilution of 2-hydroxychavicol correspondingly increased $\alpha$-glucosidase inhibitory activity (Fig.-9).

The regression analysis of the data showed a linear relationship between the isolate concentration and the percent inhibition with the determination coefficient, $\mathrm{R}^{2}$ of 0,9881 . This shows that the relationship between the variables was fairly good, in which $98,81 \%$ of the inhibition was caused by concentration factors, and there was only $1.19 \%$ which was affected by other factors. Subsequently, the $\mathrm{IC}_{50}$ calculation obtained the value of $72.87 \mathrm{ppm}$. This value indicates that the 2-hydroxychavicol has a more powerful antidiabetic activity than okra fruit extract with $\mathrm{IC}_{50}$ of $1533.74 \mathrm{ppm}^{17}$, and it is also more powerful than positive control acarbose which has $\mathrm{IC}_{50}$ of $188,5 \mathrm{ppm}^{18}$.

\section{CONCLUSION}

Based on the research results, it can be concluded that:

1. The isolation of phenolic compound 2-hydroxychavicol from Piper betel L. can be done through the column chromatography by using $\mathrm{SiO}_{2}$ as the stationary phase, followed by a preparative procedure with benzene:ethyl acetate (7:3) mixture as the mobile phase.

2. The in vitro analysis showed that the phenolic compound 2-hydroxychavicol has antidiabetic activity against $\alpha$-glucosidase enzyme with an $\mathrm{IC}_{50}$ value of $72,87 \mathrm{ppm}$.

\section{ACKNOWLEDGMENT}

This research was supported by the research grant program Penelitian Disertasi Doktor (PDD) the Ministry of Research, Technology and Higher Education, Republic of Indonesia (contract number: 117/SP2H/PPM/DRPM/2018).

\section{REFERENCES}

1. N. Kumar, P. Misra, A. Dube, S. Bhattacharya, M. Dikshit, and S. Ranade, Current Science, 99, 922 (2010).

2. V. Bajpai, D. Sharma, B. Kumar, and K. P. Madhusudanan, Biomedical Chromatography, 24, 1283 (2010), DOI: 10.1002/bmc.1437.

3. O. S. Kumari and N. B. Rao, World Journal of Pharmacy and Pharmaceutical Sciences, 4, 699 (2015).

4. B. Prakash, R. Shukla, P. Singh, A. Kumar, P. K. Mishra, and N. K. Dubey, International Journal of Food Microbiology, 142, 114 (2010), DOI: 10.1016/j.ijfoodmicro.2010.06.011 
RASĀYAN J. Chem.

Vol. 12 | No. 3 |1175 - 1184| July - September | 2019

5. L. Nouri and A. M. Nafchi, International Journal of Biological Macromolecules, 66, 254 (2014), DOI: $10.1016 /$ j.indcrop.2014.08.015.

6. D. L. Valle Jr., J. I. Andrade, J. J. M. Puzon, E. C. Cabrera, and W. L. Rivera, AsianPacific Journal of Tropical Biomedicine, 5, 532 (2015), DOI: 10.1016/j.apjtb.2015.04.005.

7. L. S. R. Arambewela, L. D. A. M. Arawwawala, and W. D. Ratnasooriya, Journal of Ethnopharmacology, 102, 239 (2005), DOI: 10.1016/j.jep.2005.06.016.

8. L. Nouri, A. M. Nafchi, and A. A. Karim, Industrial Crops and Products, 62, 47 (2014), DOI: 10.1016/j.ijbiomac.2014.02.044.

9. T. Okselni, A. Santoni, A. Dharma, and M. Efdi, Rasayan J. Chem., 12, 146 (2019), DOI: 10.31788/RJC.2019.1215019.

10. D. K. Patel, S. K. Prasad, R. Kumar, and S. Hemalatha, Asian Pacific Journal of Tropical Biomedicine, 320 (2012), DOI: 10.1016/S2221-1691(12)60032-X.

11. R.H. Mohammad, M. Nur-e-Alam, M. Lahmann, I. Parfveen, G.J. Tizzard, S.J. Coles, M. Fowler, A. F. Drake, D. Heyes, and V. Thoss, Phytochemistry, 128, 82 (2016), DOI: 10.1016/j.phytochem.2016.05.001.

12. P. Raji, A. V. Samrot, D. B. Rohan, M. D. Kumar, R. Geetika, V. K. Sharma, and D. Keerthana, Rasayan J. Chem., 12, 123 (2019), DOI: 10.31788/RJC.2019.1214054.

13. M. Silverstein, F. X. Webster, D.J. Kiemle, Spectronic Identification of Organic Compounds, John Willey and Sons, New York, pp. 350 (2005).

14. https://www.chem.wisc.edu/areas/reich/nmr/05-hmr-03-jcoupl.htm (March 19 ${ }^{\text {th }} 2018$ )

15. H. X. Liu, H. B. Tan, M. T. He, L. Li, Y. H. Wang, and C. L. Long, Tetrahedron, 71, 2369 (2015), DOI: $10.1016 /$ j.tet.2015.03.005.

16. K. Ghosh and T. K. Bhattacharya, Molecules, 10, 798 (2005).

17. W. Aligita, S. Muhsinin, E. Susilawati, Dahlia, D. S. Pratiwi, D. Aprilliani, A. Artarini, and I. K. Adnyana, Rasayan J. Chem., 12, 157 (2019), DOI: 10.31788/RJC.2019.1215059.

18. M. H. Johnson, A. Lucius, T. Meyer, and E. G. Mejia, Journal of Agricultural and Food Chemistry, 59, 8923 (2011), DOI: 10.1021/jf201720z.

19. K. Stepien, A. Dzierzega-Lecznar, I. Tam, and S. Kurkiewicz, 2013, Structure and Biological Activity of Natural Melanin Pigments, in: G. Brahmachari (Ed.), Chemistry and Pharmacology of Naturally Occuring Bioactive Compounds, CRC Press, Boca Raton, pp. 211.

[RJC-5082/2019] 